\title{
Contrasting Communication Styles in Don DeLillo's The Names
}

\author{
By Richard Gaughran*
}

\begin{abstract}
American novelist Don DeLillo's sojourn in Greece in the late 1970s gave rise to his seventh novel, The Names (1982), a work that, according to the novelist, marked a new beginning, in part because of the renewed attention to language and modes of communication (Harris, 1982: 18). The American narrator, initially an aloof observer, notices the people of Athens as they connect with each other and their environment. This mode of communication is rooted in orality, an organic, natural style of communication, one concerned with whatever is necessary to health and well-being. DeLillo's novel contrasts this organic mode of communication with the distant, technocratic, literary mode as practiced by various expatriates and a mysterious murderous cult. This study examines the ways this novel contrasts these two orientations toward language, suggesting that DeLillo's work, stemming from the writer's own experiences in Greece, privileges the organic, nourishing mode rooted in orality.
\end{abstract}

Keywords: Communication, DeLillo, Literacy, Orality.

Don DeLillo, one of the foremost contemporary American novelists, lived and worked in Athens for approximately three years, until sometime early in 1982 (LeClair, 1987: 176). With Athens as his base, he traveled elsewhere in Greece, as well as to the Middle East and India. He later said that these experiences reinvigorated his writing: "What I found ... was that all this traveling taught me how to see and hear all over again" (Harris, 1982: 18). From this new awareness emerged The Names (1982), his seventh novel. He has said, "And with this book I tried to find a deeper level of seriousness ... The Names is the book that marks the beginning of a new dedication" (Begley, 1993: 92). Although not as well known among the reading public as his subsequent novel, White Noise (1985), and perhaps surpassed in some minds by a later novel, the massive Underworld (1997), several critics at the time recognized The Names as the definitive DeLillo work. Tom LeClair, writing in In the Loop (1987), his early book-length study of DeLillo's novels, unequivocally called it the novelist's "best" and approvingly quoted a reviewer who referred to it in similar terms (LeClair, 1987: 177, 180). Likewise, David Cowart (2008), even after the publication of Underworld, could still refer to The Names as the writer's "definitive work" (Cowart, 2008: 152).

The Names is an "international novel," following in the tradition of American novelists such as Henry James. As with a Jamesian novel, readers follow Americans and other expatriates as they interact with another culture. DeLillo's novel is hardly simple, however, as it includes various subtexts and interrelated themes. Besides dramatizing the foreigners' attitudes toward their host country or countries, The Names expands the frame to include the world of political intrigue

${ }^{*}$ Associate Professor, James Madison University, USA. 
and upheaval, as it is set during the time of the Islamic Revolution in Iran. It also describes local customs, contrasts different modes of travel, and touches on the family life of its protagonists. Furthermore, it most mysteriously refers to an elusive murderous cult seemingly called Ta Onómata, The Names. The theme that binds these threads concerns language, especially in the novel's contrast of communication styles having arisen from oral culture with those that have evolved from literary culture. We might say that when DeLillo says he learned "how to see and hear," he is obliquely referring to these two modes. A literary person sees language inscribed; an orally inclined person hears the words.

The novel's narrator is the American James Axton, who describes himself as a "risk analyst," one who reviews the political and economic climate of various countries and writes reports for potential investors, highlighting whatever conditions might endanger the prospects for multinational corporations. Late in the novel, he discovers that he has unwittingly been working for a company with ties to the Central Intelligence Agency, and he thereupon resigns. But he is a technocrat, a literate person by profession and upbringing; he compiles lists that he communicates through electronic media. Demonstrating this kind of detachment, at one point he mentions that he sat in his office "wait[ing] for the telex to address [him]" (DeLillo, 1982). He deals in synthesis and abstraction. Early in the novel, he describes his estranged marriage to Kathryn and says he has compiled a list of the grievances he imagines she has against him, calling them "the 27 Depravities" (DeLillo, 1982: 16-17). He says of his talks with his wife, that they were possible when they dealt with "subjects remote from us" (DeLillo, 1982: 20).

The word remote succinctly describes the purely literate person's relationship to what Walter Ong, in his Orality and Literacy (1982), calls "the human lifeworld." Literacy entails "elaborate analytic categories that depend on writing to structure knowledge at a distance from lived experience" (Ong, 1982: 42). Kathryn, for her part, is also a detached observer, but in a way different from Axton. She finds refuge at an archeological site, scraping away at a hole on a remote island, pulling up shards of pottery from Minoan times. As Axton describes her, she is "separate from the things that surround her" (DeLillo, 1982: 132). Within the dig she has contracted her life: "She rarely looks over the rim. The trench is enough. A five-foot block of time abstracted from the system. Sequence, order, information. All she needs of herself" (DeLillo, 1982: 133).

The literate expatriates with whom Axton socializes - businessmen, bankers are likewise detached from their environments. When Axton visits Charles Maitland's apartment, he notes the way Maitland immediately retreats to the living room after opening the door: "Charles grew impatient with conversation in doorways," no doubt because it would intersect with the unpredictable life outside. Their conversation on this occasion begins with a mention of the books on shelves, which turn out to be those of Maitland's wife, Ann, as Axton realizes: "You're two distinct people, aren't you? They're hers, most of them. You read manuals, specification sheets" (DeLillo, 1982: 95). When Axton dismisses Maitland's inquiry about Axton's recent trip to Cairo by saying he was there for only a day, Maitland says, "That's all it takes. Great cities take a day" (DeLillo, 1982: 96). When the Maitlands' son Peter, a student of mathematics, arrives in Athens, Axton 
asks about the branch of mathematics the young man is studying, Charles steps in with an explanation: "He speaks to no one. He says he's not able to talk about it. There are certain things he can't discuss with his professors. It's too bloody rarified" (DeLillo, 1982: 164).

The people in Axton's circle travel widely, from capital to capital, compiling their reports, but not connecting with Ong's "human lifeworld." They speak of other countries in terms of abstract categories. The banker David Keller, for instance, refers to "his" countries as "either terrorist playpens or they're viciously anti-American or they're huge tracts of economic and social wreckage" (DeLillo, 1982: 232). His comments uncannily resemble those made by then Secretary of State Madeline Albright in a 1998 address to Howard University, when she placed the countries of the world into four categories: advanced industrial states, societies in transition, rogue states, and "basket cases," meaning failed states (St. John, 2002: 158). The emissaries of technologically developed, literate societies in DeLillo's novel create abstract categories, or as Kathryn wryly encapsulates the agenda, "Subdue and codify" (DeLillo, 1982: 80).

Axton calls himself and his associates "a subculture," connecting to foreign places from the remote vantage point of the airplane: "I flew a lot, of course. We all did. We were ... business people in transit, growing old in planes and airports" (DeLillo, 1982: 6). Later in the novel he again mentions this means of travel and its way of disengaging the traveler from the environment: "Air travel reminds us who we are. It's the means by which we recognize ourselves as modern. The process removes us from the world and sets us apart from each other. We wander in the ambient noise, checking one more time for the flight coupon, the boarding pass, the visa" (DeLillo, 1982: 254). Axton says of Greece and other countries he visits, "Americans used to come to places like this to write and paint and study, to find deeper textures. Now we do business" (DeLillo, 1982: 6), to which today we might now add - and conduct drone strikes. Axton says, "All these places were one-sentence stories to us" (DeLillo, 1982: 94). In an early review of the novel, Fredric Jameson rightly called this orientation "one of separation, suspension, rather than ontic or perceptual immersion" (Jameson, 1984: 122). It is not surprising, given this detached, mediated interaction with place, that on one more than one occasion in the novel Axton and others find themselves getting lost when riding in cars or walking, less remote means of transport.

The kind of detachment I'm describing manifests itself in a number of examples throughout the novel. David Keller, for instance, on New Year's Day wants to fly to Frankfurt to watch American football games on television (DeLillo, 1982: 194). His way of interacting with his children from an earlier marriage is to fly to New York, to sit in a hotel with them eating ice cream sundaes, then fly back. When Axton's boss, George Rowser, first appears in the novel, Axton provides him with his latest reports concerning Turkey, which he describes as "precise figures for nonperforming loans ... foreign exchange factors, inflation rates, election possibilities, exports and imports" (DeLillo, 1982: 50). The informal conversation that follows is noticeably clipped and laconic, almost monosyllabic. It ends with Axton's mocking commentary on Rowser: "He went back to his reading ... . He had a dozen nervous gestures ... . I imagined him stranded in 
Goose Bay. Big empty remote innocent Labrador ... . No politics, no risk ... . He would die there, gesturing" (DeLillo, 1982: 51). Later Axton describes Rowser's mind as binary: "on-off, zero-one" (DeLillo, 1982: 97).

Owen Brademas, Kathryn's mentor at the archeological site, emerges as a central character in the novel. He has become an epigraphist, one who studies ancient inscriptions. He admits that the content of the languages he studies mean nothing to him. His interest is purely aesthetic and detached. He says, "I've begun to see a mysterious importance in the letters as such, the blocks of characters ... . I find this is all I want to know about the people who lived there. The shapes of the letters and the materials they used" (DeLillo, 1982: 35-36). Owen's use of language becomes increasingly detached from utility and meaning. Kathryn says of him, "Owen's in another world. He's left this one behind" (DeLillo, 1982: 73). His reading of scripts has become a very private obsession. Ong would seem to be describing him when he writes, "Literates often manifest tendencies (loss of contact with the environment) by psychic withdrawal into a dreamworld of their own" (DeLillo, 1982: 68).

Ong, writing of how the evolution of print culture has affected consciousness, further explains this removal from human interaction. When words are comprehended solely in terms of visual surface, he says, the mind itself is altered, turned inward: "[P]rint encouraged human beings to think of their own interior conscious and unconscious resources as more and more thing-like ... . Print encouraged the mind to sense that its possessions were held in some sort of inert mental space" (Ong, 1982: 129). Fittingly, readers last see Owen when Axton visits him in a small room in Lahore, a room "out of the color and the light." Owen refers to it as the place he's been preparing for, containing "the correct number of objects, the correct proportions." He says, "For sixty years I've been approaching this room" (DeLillo, 1982: 275).

With the possible exception of Axton and his family, The Names provides more background information on Owen than on other characters. Readers learn that he was raised in Kansas within a Pentecostal church and has been haunted by his inability, in his youth, to experience glossolalia, speaking in tongues. According to what he was taught, this mysterious language precedes meaning, being something pure and abstract, "as from the sweet soul before birth, before blood and corruption" (DeLillo, 1982: 306). His youthful failure seems to explain much of his longing in adulthood, and it clarifies his fascination with the murderous cult, whose members choose their victims when the victim's initials match the name of the place into which he or she has wandered. For example, a feeble-minded man named Michaelis Kalliambetsos is murdered when he wanders into a village named Mikro Kamini. As critic Matthew J. Morris puts it, Owen's fascination with the purely aesthetic quality of languages, even of individual letters, leads him into complicity with murder, though this complicity stems from a wish "to do something analogous to speaking in tongues and thus to recover the sense of community he lost on that distant day" in his youth (Morris, 1989: 117).

The cult has no political agenda, no concrete cause. The killings are mechanical, reminding us of the earlier description of Rowser's mind as binary, on-off, zero-one. An apostate from the group tells Owen about the cult, and Owen 
comes to understand that the group is "intent on ritualizing a denial of our elemental nature. To eat, to expel waste, to sense things, to survive. To do what is necessary, to satisfy what is animal in us, to be organic, meat-eating, all bloodsense and digestion." The ritual involves a "needless death. A death by system, by machine-intellect" (DeLillo, 1982: 175). But this explanation explains too much, perhaps, as the apostate, Andahl, introduces what Axton's paraphrase of Owen later calls "an element of motivation, of attitudes and needs." Owen later realizes that the cult cannot be understood rationally: "No sense, no content, no historic bond, no ritual significance" (DeLillo, 1982: 216).

The yearning for a language that precedes consciousness; the interest in inscriptions apart from their content or utility; the compiling of statistical reports; the cult's machine-like murders, which the character Volterra thinks of filming from the remote distance of a helicopter - these activities arise from the desire to avoid risk and ambiguity, the stuff of life. As Owen says in feeling some empathy for the cult, "Numbers behave, words do not" (DeLillo, 1982: 208). Or as the critic Cowart puts it, the desire is "to arrest the fluidity in language, the 'free play' of signifiers" (Cowart, 2008: 162). But such desire implies something like a deathwish. It is telling that by the novel's end, the abecedarian cult members are dying off or drifting away, and Owen Brademas has been reduced to that cell-like room in Lahore, from which he presumably will not be leaving, illustrating what Morris calls "the danger of extreme critical formalism" (Morris, 1989: 124).

Against what LeClair calls the novel's "catalogue of alienations" (LeClair, 1987: 180) The Names displays uses of language more closely tied to its oral origins. Often DeLillo's chapters appear structured to dramatize the contrast. For instance, immediately after Axton records his laconic conversation with boss Rowser, mentioned earlier, he describes the street scene in Athens on a typical summer night. "Summer nights belong to people in the streets," he remarks (DeLillo, 1982: 51). He then mentions people amassing on park benches, chairs and tables being set up on sidewalks or alleys or rooftops, the blaring of music. He says, "The cars are out, the motorcycles and scooters and jeeps, and there are arguments, radios playing, the sound of auto horns" (DeLillo, 1982: 52). Similarly, just after Axton departs from Owen in Pakistan, with "no further commentary and reflection," he walks into the streets of Lahore, saying, "The alleys were full of people and noise." He suddenly has entered a realm that intimately engages the senses: "Bare bulbs were arrayed on strings over tiers of nuts and spices. I paused every few feet to see what was here, nutmeg and scarlet mace, burlap bags of coriander seeds and chilies ... . I lingered at the trays of dyestuffs and ground spices, heaped in pyramids, colors I'd never seen, brilliances, worlds ..." (DeLillo, 1982: 309).

Even Axton, early in the novel, says that he and his estranged wife could still communicate directly when the subjects remained familiar, concerning family. "The subject of family makes conversation almost tactile," he says. "I think of hands, food, hoisted children. There's a close-up contact warmth in the names and images. Everydayness" (DeLillo, 1982: 31). To call conversation almost tactile is to say it does retain a connection to the human lifeworld. Thus we also see Axton's acquaintance from India, Anand Dass, and the way his son Rajiv interacts with 
him. Rajiv seems "always to be dancing around him, asking questions, grabbing hold of the man's arm, his hand, even the loops in his belt" (DeLillo, 1982: 85-86).

As LeClair summarizes in his paraphrase of Ong's work, "In oral cultures, the ideal is harmony ... . [T] he oral culture is ... concerned with preserving what is necessary for its health and survival" (LeClair, 1987: 190). So even a seller on the street is using language intimately connected to the stuff of life. As the novel says of a peddler of lottery tickets, his repetitive pitch is a "summons to buy, to act, to live" (DeLillo, 1982: 319). Axton is, as mentioned, a literate thinker and writer, a risk analyst compiling lists and reports divorced from everydayness; but he does attend to the life around him. The vital, open, free and unhindered communication on the streets of Athens does not escape his notice. He says,

Conversation is life, language is the deepest being .... It is the sound and picture of humans communicating. It is talk as a definition of itself. Talk. Voices out of doorways and open windows, voices on the stuccoed-brick balconies, a driver taking both hands off the wheel to gesture as he speaks. Every conversation is a shared narrative, a thing that surges forward, too dense to allow space for the unspoken, the sterile. The talk is unconditional, the participants drawn in completely. This is a way of speaking that takes such pure joy in its own openness and ardor that we begin to feel these people are discussing language itself (DeLillo, 1982: 52).

Commenting on this passage, Jameson contrasts this use of language with that of the technocratic expatriates:

[T]he "concept" of language is not some end in itself, some ultimate formal stopping place which then becomes closure and mandala, decoration and provisional metaphysics; rather, it here lives from a content it has drawn from another place and another thematics, namely that of social life proper (Jameson, 1984: 120).

The novel begins with Axton's mentioning that he long postponed a trek to the Acropolis. He assumed that such a visit would be too weighty, the "somber rock" too daunting, and he speaks of the ancient structure in abstract terms: "Beauty, dignity, order, proportion" (DeLillo, 1982: 3). However, late in the novel Axton makes the trip and is startled by what he finds:

[T] he Parthenon was not a thing to study but to feel. It wasn't aloof, rational, timeless, pure .... It wasn't a relic species of dead Greece but part of the living city below it. This was a surprise. I'd thought it was a separate thing, the sacred height, intact in its Doric order. I hadn't expected a human feeling to emerge from the stones but this is what I found, deeper than the art and mathematics embodied in the structure, the optical exactitudes. I found a cry for pity (DeLillo, 1982: 330).

In these closing passages of Axton's narrative, The Names celebrates something like a Tower of Babel, preferring its multiplicity of voices, its 
secularity, and ultimately its humanity rather than the pure connection of word to world sought by the cultists or the "invisible spirit's voice" sought by the Pentecostalists (DeLillo, 1982: 337). As Axton further describes the scene on the Acropolis, he says,

No one seems to be alone. This is a place to enter in crowds, seek company and talk. Everyone is talking. I move past the scaffolding and walk down the steps, hearing one language after another, rich, harsh, mysterious, strong. This is what we bring to the temple, not prayer or chant or slaughtered rams. Our offering is language (DeLillo, 1982: 331).

Jameson argues that Axton's reaction here is suspect, that he is, in a sense, still the distant observer who thinks of language abstractly, and by implication so are we readers who find pleasure in such a passage: "[T]he motif of Language has been reified, turned into a pseudo-concept, one which is supposed to send religious vibrations through one if one is a believing post-structuralist" (Jameson, 1984: 120). To be sure, one cannot undo literacy; the pathway to a pre-literate, pretechnological past is blocked for the novel's Westerners - and by extension for the novel's readers. Yet, I argue that the Parthenon passage constitutes progress for Axton. He is now presumably less likely to compose "the 27 Depravities" or attempt to subdue the exotic dancer Janet Ruffing through an assault of defamiliarized language (DeLillo, 1982: 222-230).

Purely spontaneous, natural language may be inaccessible for the post-literate observer, but DeLillo's novel does privilege communication and noise that arises from what Axton calls "the spoken universe" (DeLillo, 1982: 94), as LeClair argues. As LeClair further notes, Axton changes and becomes more self-aware not through his reading but through his experiences and his listening to others (DeLillo, 1982: 197; LeClair, 1987: 189). An obvious paradox still remains, however: DeLillo himself is a writer, and The Names is a printed text, not oral literature. In his "Murdering Words: Language in Action in Don DeLillo's The Names," Morris has pointed out that within the novel DeLillo himself plays with language in a formal, not organic way. Morris notes that there are echoes, ultimately meaningless, between names like Del Nearing and DeLillo, between Charles Maitland and Mainland bank; further, Kathryn's "ob" language precedes her acquaintance with Owen Brademus (Morris, 1989: 124). "[T]he novel's textual world is more text than world ... it contains ... many features related formally but not causally" (Morris, 1989: 125).

However, The Names does not end when Axton's narration does, for it contains an epilogue written by Axton's young son, nicknamed Tap. Readers early learn that Tap has been writing a novel, and we also have heard that he is a notoriously bad speller. The final pages of DeLillo's novel give us what is presumably a portion of Tap's narrative, with misspellings that derive from hearing language spoken, not from seeing words written. One of his characters "smelt of spoilt milk"; his main character, a fictionalized Owen Brademas named Orville Benton, is encouraged to "yeeld totally" in order to speak in tongues (DeLillo, 1982: 335, 336). 
In this chapter DeLillo, through Tap, is experimenting with a synthesis between orality and literacy. Axton earlier mentioned Tap's misspellings, calling them "spirited," and he gives the example of Tap's writing "burch cruch" instead of "birch crutch." Axton comments further: "This term had a superseding rightness as it appeared on the page. It found the spoken poetry in those words, the rough form lost through usage. His other misrenderings were wilder, freedom-seeking, and seemed to contain curious perceptions about the words themselves, second and deeper meanings, original meanings" (DeLillo, 1982: 313). DeLillo has explained that his inspiration and partial source for Tap's chapter came from his seeing the work of then nine-year-old Atticus Lish, the son of Gordon Lish. Because of its "simple exuberance," what DeLillo read "seemed to insist on being used," he has said: "In other words, I stole from a kid" (Harris, 1982: 17). The anecdote amounts to an admission that there is no turning back for the literate adult, but it also attests to the value of what has been lost.

The novel is not arguing for an impossible return to pure orality, but it recognizes that there is a tradeoff, with gains and losses for humans as they grow in literate sophistication. The novel seeks to find ways of restoring and preserving an intimate connection with the world, its peoples, and ourselves. I recently stumbled upon an anecdote about Samuel Johnson's blind housekeeper, who, in order to determine the level of the tea in a cup would put her finger in it. It's an apt image: some knowledge is best gained through direct, intimate experience. Or, as my wife likes to remind me, when I want to know the weather I should stop staring at the radar images on the computer screen and instead step outside the door.

\section{References}

Begley, A. (1993). The art of fiction CXXXV: Don DeLillo. In: T. DePietro (Eds.), Conversations with Don DeLillo. Jackson, Mississippi: University Press of Mississippi, pp.: 86-108.

Cowart, D. (2008). DeLillo and the power of language. In: J. N. Duvall (Eds.), The Cambridge Companion to Don DeLillo. New York, NY: Cambridge University Press, pp.: 151-165.

DeLillo, D. (1982). The Names. New York, NY: Vintage Press.

Harris, R. (1982). A talk with Don DeLillo. In: T. DePietro (Eds.), Conversations with Don DeLillo. Jackson, Mississippi: University Press of Mississippi, pp.: 16-19.

Jameson, F. (1984). The Names and Richard A (review). Minnesota Review 22(1): 116-122.

LeClair, T. (1987). In the Loop: Don DeLillo and the Systems Novel. Illinois: University of Illinois Press in Urbana.

Morris, M. J. (1989). Murdering words: language in action in Don DeLillo's The Names. Contemporary Literature 30(1): 113-127.

Ong, W. J. (1982, 2002). Orality and Literacy. London: Routledge Press.

St. John, R. B. (2002). Libya and the United States, Two Centuries of Strife. Philadelphia: University of Pennsylvania Press 